International Journal of Biological Research, 3(1)(2015) 25-35
International Journal of Biological Research
SPC
Journal home page: www.sciencepubco.com/index.php/IJBR
doi: $10.14419 /$ ijbr.v3il.4301
Research Paper

\title{
Comparative efficacy of Albendazole, Fenbendazole and Levamisole against gastrointestinal nematodiasis in cattle of Bangladesh
}

\author{
Md. Monirul Islam ${ }^{1}$, Md. Siddiqul Islam ${ }^{1}$, Md. Matiar Rahman Howlader ${ }^{2}$, Nasrin Sultana Lucky ${ }^{3 *}$ \\ ${ }^{I}$ Department of Pharmacology, Faculty of Veterinary and Animal Science, Sylhet Agricultural University, Sylhet, Bangladesh \\ ${ }^{2}$ Department of Physiology, Faculty of Veterinary and Animal Science, Sylhet Agricultural University, Sylhet, Bangladesh \\ ${ }^{3}$ Department of Surgery and Theriogenology, Faculty of Veterinary and Animal Science, Sylhet Agricultural University, Sylhet, Bangladesh \\ *Corresponding author E-mail: nslucky.10@gmail.com
}

\begin{abstract}
Out of 52 cattle 30 were heavily infested with different gastrointestinal nematodes which were identified by faecal examination. Among 30 cattle 20 were selected randomly and divided into four groups (A, B, C and D). Group D was kept as infected control group. Group A, $\mathrm{B}$ and $\mathrm{C}$ were treated with patent drug Albendazole (Helmex-vet ${ }^{\circledR} 600 \mathrm{mg} / \mathrm{Tab}$ ) 7.5, Fenbendazole (Peraclear $\left.{ }^{\circledR} 250 \mathrm{mg} / \mathrm{bolus}\right) 7.5 \mathrm{and}$ Levamisole (Ralnex ${ }^{\circledR} 708 \mathrm{mg} / \mathrm{bolus}$ ) $7.5 \mathrm{mg} / \mathrm{kg}$ body weight orally for the determination of effects on blood parameters. Before trials with Helmex-vet ${ }^{\circledR}$, Peraclear ${ }^{\circledR}$ and Ralnex ${ }^{\circledR}$ initial total egg count of gastrointestinal helminths and haematological parameters were examined and recorded. During the experimental period the faecal samples were examined on 7th, 14th, 21st and 28th day. Haematological parameters (TEC, Hb, ESR, TLC and PCV) were also examined from 7 to 28 days for the determination of effects of Helmex-vet ${ }^{\circledR}$, Peraclear ${ }^{\circledR}$ and Ralnex ${ }^{\circledR}$. A significant reduction of EPG of gastrointestinal nematodes were found on 7th, 14th, 21st and 28th day of Helmex-vet ${ }^{\circledR}(46.91 \%, 72.84 \%, 84.44 \%$ and $93.58 \%)$, Peraclear ${ }^{\circledR}(46.67 \%, 71.67 \%, 83.33 \%$ and $90.56 \%)$ and Ralnex ${ }^{\circledR}(49.27 \%$, $72.82 \%, 93.93 \%$ and $85.80 \%$ ) of group A, B and C respectively. The EPG of untreated group were significantly increased about 3.37\%, $6.75 \%, 8.13 \%$ and $9.69 \%$ on 7 th, 14 th, 21 st and 28 th day respectively. After treatment with Helmex-vet ${ }^{\circledR}$, Peraclear ${ }^{\circledR}$ and Ralnex ${ }^{\circledR}$, TEC, Hb, TLC and PCV were increased and ESR were decreased in cattle. On the other hand, TEC, Hb, TLC and PCV were decreased and ESR was increased significantly $(\mathrm{p}<0.05)$ in untreated group.
\end{abstract}

Keywords: Anthelmintics; Cattle; Gastrointestinal Helminths; Heamatological Parameters; Nematodiasis.

\section{Introduction}

Bangladesh is an agro-economy based, densely populated developing country. About $80 \%$ people of Bangladesh live in village and most of them are fully or partially depended on agriculture. The contribution of agricultural sector on the gross domestic product (GDP) is $20.16 \%$ (Economic Index, 2010). Among all agricultural activities cattle farming occupy large area. According to the report of the Department of Livestock Services (DLS) Bangladesh, the cattle population of this country is 22.90 million. In 2007-2008 the amount of deficit demand of milk and meat is 10.36 and 5.22 million metric ton. In Bangladesh more than 80\% rural people rear indigenous cattle. While at present many crossbred cattle are available throughout the country, there are a few original varieties of cattle localized in some areas of Bangladesh and also have better performance compared to other available indigenous breeds. The Red Chittagong (RC) cattle is one of such varieties of cattle which are usually found in Chittagong district and Chittagong hill tract region and are rare in other parts of Bangladesh. There are few literatures available on the performance of RC cattle which is not internationally considered as a pure breed but as a variety (Mason and Buramendram, 1982). However, it has been reported that the RC cattle require lower input support than other indigenous cattle with high quality milk and beef production (Bhuiyan, 2007). The present study was, therefore, designed to explore the status of parasitic diseases prevalent in RC cattle through classical coproscopic and blood smear analysis.

The cattle farming are facing various constraints in Bangladesh and parasitic diseases are the most common among the problems. The cattle kept at high level of nutrition and in better management yet declined in their health and productivity, due to their regular infestation with gastrointestinal parasites. Gastrointestinal nematodes of ruminant include Haemonchus sp, Mecistocirrus sp, Trichuris sp, Bunostomum sp, Oesophagostomum sp, Ostertazia sp, Cooperia sp, Trichostrongylus sp, Capillaria sp, etc. (Ahmed 1972, Hosking et al. 2008, Samanta and Santra 2009). These nematodes are responsible for significant losses through severe morbidity and mortality in livestock of all over the Bangladesh. These parasites cause anorexia, reduced feed intake, loss of blood and plasma proteins, alteration in protein metabolism, low level of mineral intake, lowered activity of some intestinal enzymes and subsequently leading to diarrhoea, reduced weight gain and milk production, loss of production rate, poor general health condition and even mortality (Soulsby1982). 
Parasitic infestation is the major cause hindering the development of livestock population in the country (Shahiduzzaman et al. 1999). Several studies have indicated the incidence of different parasitic diseases and their seasonal prevalence in cattle of Bangladesh (Rahman and Razzak 1973). These parasitic infections are more severe in younger animals than adults. Fasciolosis is reported to be one of the important diseases of cattle and small ruminants in the country (Qadir, 1981). Similarly, gastrointestinal nematodes are also serious problems for ruminants, especially young animals. Previous reports suggest that $50 \%$ cattle up to one year of age died due to gastrointestinal parasites that cause digestive disturbances and malnutrition leading to calf mortality (Debnath et al. 1995). Different helminth infections are responsible for about $54.22 \%$ calf mortality in Bangladesh. Strongyles are another harmful group of bovine parasites due to their feeding habit or development process in the digestive system (Shahiduzzaman et al. 1999). Asian development Bank ADB (1984) estimated that the loss of animal production due to parasitic diseases was $50 \%$ in Bangladesh. 0.1 million taka as an annual economic loss due to various parasitic diseases at the Savar Military Dairy Farm, Dhaka. (Motalib and Alam (1983) reported that, the decreased growth rate and $7 \%$ mortality in young calves due to helminth infection in Pabna milk-shed areas of Bangladesh.

Parasitic gastroenteritis (PGE) is an omnipresent pathologic condition of most cattle with multiple agents, etiologies, and degrees of detriment. The offending agents are primarily helminth (nematode, trematode, and cestode). Given the consistent nature of PGE and the non-tenable objective of complete protection for grazing animals, measures of chemical control are practiced for therapeutic action (treatment for ongoing PGE), prophylactic action (treatment for prolonged avoidance of economically apparent disease), or a combination of these two measures. In regard to nematode infections, a good number of effective anthelmintics are available in the market of Bangladesh. Among these Albendazole (Helmex-vet ${ }^{\circledR}$, Renata Limited, Bangladesh); Fenbendazole (Peraclear ${ }^{\circledR}$, Techno Drugs, Bangladesh) and Levamisole (Ralnex ${ }^{\circledR}$, Novartis, Bangladesh Limited) are widely used for the treatment of gastrointestinal Nematodiasis.

The present research work was conducted on the gastrointestinal nematodiasis in cattle at Sreenagar milk shed area (Milk vita) in Munshigonj District and was undertaken to study the comparative efficacy of Albendazole (Helmex-vet $\left.{ }^{\circledR}\right)$, Fenbendazole (Peraclear $\left.{ }^{\circledR}\right)$ and Levamisole (Ralnex $\left.{ }^{\circledR}\right)$ against gastrointestinal nematodiasis in cattle and their influence on hematological parameters (TEC, Hb, ESR, TLC and PCV) in cattle.

\section{Materials and methods}

\subsection{Study area}

This research work was carried out from January to May, 2010 in local dairy farm at Sreenagar milk shed area (Milk vita) in Munshigonj District, Bangladesh in collaboration with the department of Physiology and Pharmacology, Sylhet Agricultural University, Sylhet, Bangladesh. The following procedures were adopted for performing of the research work.

The research work consisted of the following parts

i) Selection and grouping of the animals

ii) Collection of drugs and chemicals

iii) Design of experiment

iv) Fecal sample examination

v) Determination of hematological parameters

vi) Analysis of the results and calculation

\subsection{Selection and grouping of the animals}

Fecal samples from about 52 cattle (Both local and cross breed 1.5-3 years old) were examined by direct smear, flotation methods (Soulsby, 1986) and Egg counting Mc. Master Methods. A total of 20 positive cases were randomly selected and divided into 4 groups (A, B, C and D). Each group consists of 5 cattle which were both male and female.

\subsection{The test parasites}

Gastrointestinal nematodes were used as test parasites in this study. The most important gastrointestinal nematodes of cattle were Strongylids (Haemonchus sp., Mecistocirrus sp.), Trichuris sp., Trichostrongylus sp., Oesophagostomum sp. and Bunostomum sp.

\subsection{Collection of drugs and chemicals}

Three modern anthelmintics were purchased from local market

i) Tab. Helmex-vet ${ }^{\circledR}$ (Albendazole, Renata Limited, Bangladesh).

ii) Tab. Peraclear® (Fenbendazole, Techno Drugs).

iii) Tab. Ralnex ${ }^{\circledR}$ (Levamisole hydrochloride, Novartis, Bangladesh limited).

In addition, saturated salt solution, normal saline $(0.9 \% \mathrm{NaCl}$ solution), Anticoagulant (Sodium citrate 3.8\%) Hayem's solution, $0.14 \% \mathrm{HCl}$ solution was prepared in the laboratory during the experiment.

\subsection{Design of experiment}

Out of 52 cattle 30 cattle were heavily infested with different gastrointestinal nematodes which were identified by faecal examination in the laboratory. Among 30 cattle, 20 were randomly selected for this experiment and divided into four equal groups (group A B, C and D). Each group consisting of 5 cattle. Cattle of group D was kept as infected control group. Rest groups (Group A, B and C) of cattle were treated with patent drug Albendazole (Helmexvet巴) $600 \mathrm{mg} / \mathrm{Tab}$ ) $7.5 \mathrm{mg} / \mathrm{kg}$ body weight orally, Fenbendazole (Peraclear®) $250 \mathrm{mg} /$ bolus) $7.5 \mathrm{mg} / \mathrm{kg}$ body weight orally and Levamisole (Ralnex®) $708 \mathrm{mg} /$ bolus) $7.5 \mathrm{mg} / \mathrm{kg}$ body weight orally for the determination of effects of these anthelmintics on blood parameters.

Layout of experiment:

\begin{tabular}{|c|c|c|c|c|c|c|}
\hline \multirow{2}{*}{$\begin{array}{l}\text { Groups } \\
\text { of } \\
\text { cattle }\end{array}$} & \multirow{2}{*}{ Treatment } & \multirow{2}{*}{$\begin{array}{l}\text { Time of days } \\
\text { Pre treatment } \\
\text { Day } 0\end{array}$} & \multicolumn{3}{|c|}{ Post-treatment } & \multirow[b]{2}{*}{$\begin{array}{l}\text { Day } \\
28\end{array}$} \\
\hline & & & $\begin{array}{l}\text { Day } \\
7\end{array}$ & $\begin{array}{l}\text { Day } \\
14\end{array}$ & $\begin{array}{l}\text { Day } \\
21\end{array}$ & \\
\hline A & $\begin{array}{l}\text { Albendazole } \\
\text { (Helmex- } \\
\text { vet }())\end{array}$ & $\bullet$ & $\bullet$ & $\bullet$ & $\bullet$ & $\bullet$ \\
\hline B & $\begin{array}{l}\text { Fenbendazole } \\
\text { (Peraclear®) }\end{array}$ & 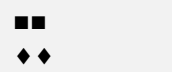 & 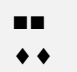 & $\bullet$ & $\bullet$ & 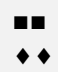 \\
\hline $\mathrm{C}$ & $\begin{array}{l}\text { Levamisole } \\
\text { (Ralnex®) }\end{array}$ & 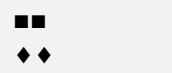 & $\bullet$ & $\bullet$ & $\bullet$ & $\square$ \\
\hline D & $\begin{array}{l}\text { Untreated } \\
\text { infected } \\
\text { control }\end{array}$ & $\bullet$ & $\bullet$ & $\bullet$ & $\bullet$ & $\bullet$ \\
\hline$\bullet$ & $\begin{array}{l}\text { Faecal sample exa } \\
\text { Hematological tes }\end{array}$ & $\begin{array}{l}\text { nination } \\
\mathrm{s} \text { (TEC, } \mathrm{Hb}, \mathrm{E}\end{array}$ & , TLC & and 1 & & \\
\hline
\end{tabular}

\subsection{Faecal sample examination}

The sufficient amount of faecal samples were collected from the rectum by hand with gloves, was kept in polythene bag and these were marking with Tag number. These were brought to the laboratory and examined by different methods.

a) By direct smear method

A small quantity of faeces was placed on a glass slide and 1-2 drops of tap water was poured on it. The diluted faeces were spreads over the slide by glass rod. The coarse undigested materials were removed by glass rod, covered with cover slip and the slide was examined directly under microscope with low power (10 $\times 6$ ocular) lens. At least two slides from each faecal sample were examined.

b) By flotation method 
About $5 \mathrm{gm}$ of faeces was placed in a beaker and $25 \mathrm{ml}$ saturated salt solution was poured on it. The faeces were mixing by using glass rod. The faecal suspension was then strained and the filtrate was poured inside the glass vial up to its top. The glass slide was placed on it for touching the surface of the flaccid and kept for about 30 minutes, after which the glass slide was removed. The flaccid adhering to the slide was covered with cover slip and examined under microscope with low power and occasionally high power lens. The parasitic eggs were identified, Soulsby (1986).

c) Egg counting Mc. Master method

5 gm faecal sample was taken in a beaker. $45 \mathrm{ml}$ saturated salt solution was added in the beaker and mixed thoroughly. The mixture was then sieved to remove coarse particles. Chambers (2) of the Mc. Master slide were filled with suspension (Each chamber contain $0.15 \mathrm{ml}$ suspension) and left for 3-5 minutes. Therefore the slide was examined under microscope using 10x objectives and $7 x$ eye pieces.

The number of eggs per gram (EPG) of faeces was calculated.

The egg per gram (EPG) of faeces was counted on day " 0 " before giving treatment and on 7th, 14th, 21st and 28th post treatment day. Faecal samples were counted from each animal of both treatment and control groups. Fresh samples were collected before each examination.

\subsection{Determination of hematological parameters}

About 5-10ml blood sample of each animal was collected from Jugular vein by using sterile syringe and needle in vials containing anticoagulant (sodium E.D.T.A) on pre and post treatment day of "0", 7th, 14th, 21st and 28th.

Collection of blood:

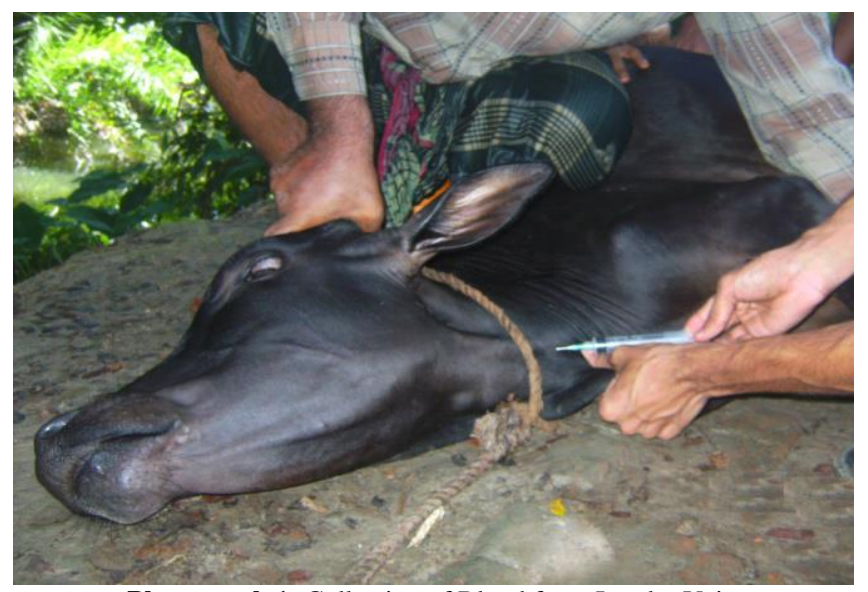

Photograph 1: Collection of Blood from Jugular Vein

For the haematological examination, blood was collected aseptically with sterile syringe and needle from the jugular vein of cattle. Approximately $5 \mathrm{ml}$ of blood was collected from jugular vein of each animal and was transferred immediately to a clean, dried glass vial containing anticoagulant (Sodium citrate) at day 0 (pretreatment) and $7 \mathrm{th}, 14 \mathrm{th}, 21 \mathrm{st}$ and $28 \mathrm{th}$ day of post-treatment period. Then the collecting blood samples were shifted to the laboratory in the CDIL (Central Disease investigation laboratory), Dhaka, Bangladesh. The haematological studies were performed within five hours after collection of blood. The routine analysis of blood was carried out by the standard method as described by Schalm (1965) and Coffin (1995). The following parameters were studied during the experimental period for fulfilling the objectives:

i) Total Erythrocyte Count (TEC).

ii) Hemoglobin content $(\mathrm{Hb} \%)$.

iii) Erythrocyte Sedimentation Rate (ESR).

iv) Total Leukocyte Count (TLC)

v) Packed Cell Volume (PCV).

\subsubsection{Total erythrocyte count (TEC)}

a) The tip of the dry clean red blood cell pipette was placed on the blood.

b) Gently the blood was sucked up until reached the exactly 0.5 mark.

c) Carefully the tip of the pipette was wiped with a piece of cotton.

d) Then the tip of the pipette was placed immediately in the diluting fluid (Hayem's Solution) and filled the pipette exactly up to 101 marks.

e) The rubber tube was stretched around the tip of the pipette and held with thumb and finger at each end.

f) The content of the pipette was shaken thoroughly with 8 knot for 1-2 minutes.

g) The counting chamber with cover glass was placed under the microscope and visible rolled area was focused with low powder objective.

h) After discarding 2-3 drops, a small drop from the pipette was placed to the end of polished surface of the counting chamber and allowed the space to fill the area under cover glass.

i) The counting chamber was allowed to stand for a minute to allow the erythrocyte to settle.

j) Then the cells were started to count with the high power objective $(45 x)$.

k) The central squares of the counting chamber were used for erythrocyte count.

1) Red blood cells (RBC) were count in the four corner squares and one centre square of the chamber.

The number of RBC was calculated as follows:

Number of RBC $=$ No. of cell count $\times 10000$ and expressed the results in million per cu. $\mathrm{mm}$.

\subsubsection{Hemoglobin (Hb) content}

a) $\mathrm{N} / 10 \mathrm{HCl}$ solution was taken in the perfectly clean and dry special graduated tube up to its $2 \mathrm{gm} \%$ mark.

b) The special Sahli pipette was filled with blood up to 20 marks and wiped its side with absorbent cotton.

c) Immediately the blood of the pipette was transferred into the diluting tube containing $\mathrm{N} / 10 \mathrm{HCl}$ solution and rinsed the pipette 2-3 times by sucking water into the pipette and added water to the solution in the tube.

d) The tube was shacked until the blood was well mixed with $\mathrm{N} / 10 \mathrm{HCl}$ solution and water and the mixture appeared uniformly dark brown color.

e) Using the dropper, water was added drop by drop each time mixing the solution with a stirrer until color of the solution matched with the standard.

f) After 5 minutes of first noting time the result was read in daylight from the scale of measuring tube by observing the graduated mark at the lower edge of the meniscus at the top of the liquid column.

g) The result was expressed in gm \%.

\subsubsection{Determination of erythrocyte sedimentation rate (ESR)}

a) The citrated blood was drawn into the special loading pipette.

b) The tip of the pipette was inserted to the bottom of a clean, dry Wintrobe heamatocrit tube.

c) The rubber bulb of the pipette was pressed continuously to expel the blood out of the pipette.

d) The Wintrobe heamatocrit tube was filled from the bottom.

e) As blood came out, the pipette was slowly withdrawn but pressure was continued on the rubber bulb of the pipette so as to exclude air bubbles. The tip of the pipette was tried to keep under the rising column of the blood to avoid foaming.

f) The tube was filled exactly up to 0 of the left sided scale.

g) The filled tube was kept standing in a vertical position on a standing rack for an hour. 
h) After elapsing one hour the reading was taken from the scale at the top of the tube and the result was expressed in millimeter in first hour $\left(\mathrm{mm} / 1^{\text {st }}\right.$ hour$)$.

\subsubsection{Total leukocyte count (TLC)}

The principles of counting TLC were almost same to those of erythrocytes. Here the leukocyte diluting fluid was N/10 HCI solution. Well mixed blood was drawn up to the 0.5 mark of white blood cell pipette. The diluting fluid was filled up to the 11 mark of the pipette and the contents were thoroughly mixed for 2 minutes. 2-3 drops of content were discarded and counting chamber was then filled in the same way as in the red blood cell count. The counting chamber was placed under the microscope and examined under low power objectives (10x). The leukocytes in the 4 large squares (each 1 square $\mathrm{mm}$ of the counting chamber was counted.

The number of WBC was calculated as follows:

Number of $\mathrm{WBC}=$ No. of cell counted $\times 50$ and expressed the result in thousand per cu. $\mathrm{mm}$.

\subsubsection{Packed cell volume (PCV)}

a) The citrated blood was drawn into the special loading pipette.

b) The tip of the pipette was inserted to the bottom of a clean, dry Wintrobe hematocrit tube.

c) The rubber bulb of the pipette was pressed continuously to expel the blood out of the pipette.

d) The wintrobe hematocrit tube was filled from the bottom.

e) As blood came out, the pipette was slowly withdrawn but pressure was continued on the rubber bulb of the pipette so as to exclude air bubbles. The tip of the pipette was tried to keep under the rising column of the blood to avoid air bubble.

f) The tip was filled exactly to the 10 mark of the right sided scale Excess blood above the mark was wiped away by means of cotton

g) The tubes were then placed in a centrifuge machine and centrifuged for 30 minutes at $3000 \mathrm{rpm}$.

h) After 30 minutes the tubes were taken out of centrifuge machine and PCV was read directly of the calibration on the right side of the tube.

i) The result was expressed in percentage (\%) using the formula: $\mathrm{PCV}=$ weight of the packed Red cell in $(\mathrm{cm}) /$ weight of the total blood in the tube $(\mathrm{cm}) \times 100$

\subsection{Analysis of the result and calculation}

The data were analyzed statistically by using student "T" test. (Gupta, 1978)

Table 1: Comparative efficacy of Albendazole (Helmex-Vet $\left.{ }^{\circledR}\right)$, Fenbendazole (Peraclear ${ }^{\circledR}$ ) and Levamisole (Ralnex $($ ) against gastrointestinal Nematodiasis in Cattle

\begin{tabular}{|c|c|c|c|c|c|c|}
\hline Groups & Drug with Doses & $\begin{array}{l}\text { Pre-treatment } \\
\text { EPG at '0' day } \\
\text { Mean } \pm \text { SE }\end{array}$ & $\begin{array}{l}\text { Post treatment } \\
\text { EPG at } 7 \text { th day } \\
\text { Mean } \pm \text { SE }\end{array}$ & $\begin{array}{l}\text { EPG at } 14 \text { th day } \\
\text { Mean } \pm \text { SE }\end{array}$ & $\begin{array}{l}\text { EPG at } 21 \text { st day } \\
\text { Mean } \pm \text { SE }\end{array}$ & $\begin{array}{l}\text { EPG at 28th day } \\
\text { Mean } \pm \text { SE }\end{array}$ \\
\hline A & $\begin{array}{l}\text { Albendazole (Helmex-vet巴) } 600 \\
\text { mg/Tab) } 7.5 \mathrm{mg} / \mathrm{kg} \text { b.wt orally }\end{array}$ & $810 \pm 33.17$ & $\begin{array}{l}430 * * \pm 20.00 \\
(46.91 \%)\end{array}$ & $\begin{array}{l}220 * * \pm 9.49 \\
(72.84 \%)\end{array}$ & $\begin{array}{l}126^{* *} \pm 9.80 \\
(84.44 \%)\end{array}$ & $\begin{array}{l}52 * * \pm 4.90 \\
(93.58 \%)\end{array}$ \\
\hline B & $\begin{array}{l}\text { Fenbendazole (Peraclear®) } 250 \\
\mathrm{mg} / \text { bolus) } 7.5 \mathrm{mg} / \mathrm{kg} \text { b.wt orally }\end{array}$ & $720 \pm 25.50$ & $\begin{array}{l}384 * * \pm 14.35 \\
(46.67 \%)\end{array}$ & $\begin{array}{l}204 * * \pm 7.48 \\
(71.67 \%)\end{array}$ & $\begin{array}{l}120 * * \pm 5.48 \\
(83.33 \%)\end{array}$ & $\begin{array}{l}68 * * \pm 3.74 \\
(90.56 \%)\end{array}$ \\
\hline $\mathrm{C}$ & $\begin{array}{l}\left.\text { Levamisole (Ralnex }{ }^{\circledR}\right) \\
708 \mathrm{mg} / \text { bolus) } 7.5 \mathrm{mg} / \mathrm{kg} \text { b.wt } \\
\text { orally }\end{array}$ & $824 \pm 25.02$ & $\begin{array}{l}418 * * \pm 25.38 \\
(49.27 \%)\end{array}$ & $\begin{array}{l}224 * * \pm 12.08 \\
(72.82 \%)\end{array}$ & $\begin{array}{l}117 * * \pm 3.74 \\
(85.80 \%)\end{array}$ & $\begin{array}{l}50 * * \pm 3.16 \\
(93.93 \%)\end{array}$ \\
\hline $\mathrm{D}$ & Control & $746 \pm 20.40$ & $\begin{array}{l}772 * * \pm 20.83 \\
(3.37 \%)\end{array}$ & $\begin{array}{l}800 * * \pm 18.17 \\
(6.75 \%)\end{array}$ & $\begin{array}{l}812 * * \pm 18.28 \\
(8.13 \%)\end{array}$ & $\begin{array}{l}826 * * \pm 8.60 \\
(9.69 \% 0\end{array}$ \\
\hline
\end{tabular}

Within the parenthesis value showing (\% increase and decrease)

The above values represent the mean \pm SE of 5 cattle

$* *=$ Significant at 1 percent level $(\mathrm{p}<0.01)$

$*=$ Significant at 5 percent level $(\mathrm{p}<0.05)$
$\frac{\mathrm{N}_{1}-\mathrm{N}_{2}}{\mathrm{~N}_{1}} \times 100$

The percentage of reduction of EPG was calculated as

$\mathrm{N} 1=$ Number at day " 0 "

\section{Resutls}

The research work was conducted to evaluate the comparative efficacy of gastrointestinal nematodiasis in cattle at Sreenagar milk shed area (Milk vita), in Munshigonj district for the period of five months from January' 2010 through May' 2010. The present investigation was carried out to determine the comparative efficacy of locally available anthelmintics Albendazole (Helmex-vet ${ }^{\circledR}$, Renata Limited, Bangladesh), Fenbendazole (Peraclear ${ }^{\circledR}$, Techno Drugs Limited) and Levamisole (Ralnex ${ }^{\circledR}$, Novartis Limited, Bangladesh) against gastrointestinal nematodiasis in 1.5-3 years old cattle.

3.1. Studies on comparative efficacy of Albendazole (Helmex-vet $\left.{ }^{\circledR}\right)$, Fenbendazole (Peraclear ${ }^{\circledR)}$ and Levamisole (Ralnex $\left.{ }^{\circledR}\right)$ against gastrointestinal nematodiasis in cattle

The results on the comparative efficacy of anthelmintics are summarized in Table 1 and shown in Figure 1.

In group A: Mean EPG count before treatment was $810 \pm 33.17$ and after treatment with Helmex-vet ${ }^{\circledR}$ mean EPG on 7th, 14th, 21st and 28th day were $430 \pm 20.00,220 \pm 9.49,126 \pm 9.80$ and $52 \pm 4.90$ respectively. Reduction of mean EPG on 7th, 14th, 21st and 28th day after treatment were $46.91 \%, 72.84 \%, 84.44 \%$ and $93.58 \%$ respectively.

In group B: Mean EPG count before treatment was $720 \pm 25.50$ and after treatment with Peraclear ${ }^{\circledR}$ mean EPG on 7 th, 14th, 21st and 28 th day were $384 \pm 14.35,204 \pm 7.48,120 \pm 5.48$ and $68 \pm 3.74$ respectively. Reduction of mean EPG on 7th, 14th, 21st and 28th day after treatment were $46.67 \%, 71.67 \%, 83.33 \%$ and $90.56 \%$ respectively.

In group C: Mean EPG count before treatment was $824 \pm 25.02$ and after treatment with Ralnex ${ }^{\circledR}$ mean EPG on 7th, 14th, 21st and 28th day were $418 \pm 25.38,224 \pm 12.08,117 \pm 3.74$ and $50 \pm 3.16$ respectively. Reduction of mean EPG on 7th, 14th, 21st and 28th day after treatment were $49.27 \%, 72.82 \%, 93.93 \%$ and $85.80 \%$ respectively.

In group D: EPG of the control Group D was $746 \pm 20.40$ on " 0 " day, which increased to $826 \pm 18.60$ on the 28 th day.
$\mathrm{N} 2=$ Number on next counting day 


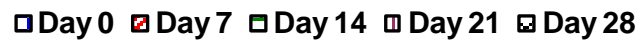

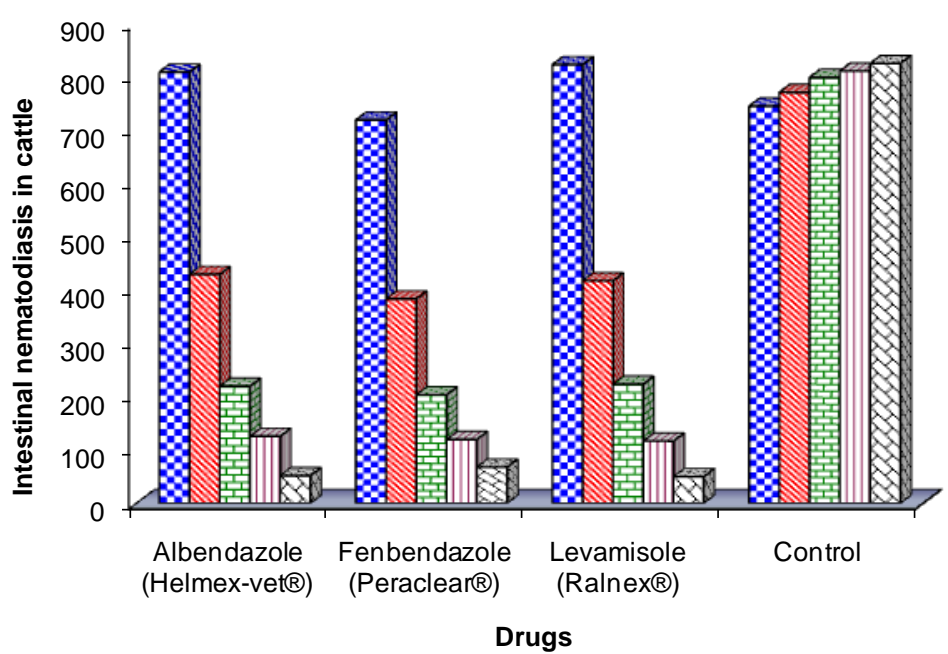

Fig. 1: Comparative efficacy of Albendazole (Helmex-Vet $\left.{ }^{\circledR}\right)$, Fenbendazole (Peraclear $\left.{ }^{\circledR}\right)$ and Levamisole (Ralnex $\left.{ }^{\circledR}\right)$ against gastrointestinal nematodiasis in Cattle

\subsection{Studies on the effect of Albendazole (Helmex-vet ${ }^{\circledR}$ ), Fenbendazole (Peraclear $\left.{ }^{\circledR}\right)$ and Levamisole (Ralnex®) on hematological parameters}

\subsubsection{Total erythrocyte count (TEC, million/cu.mm. of blood)}

The effect of Albendazole (Helmex-vet $\left.{ }^{\circledR}\right)$, Fenbendazole (Peraclear $\left.{ }^{\circledR}\right)$ and Levamisole (Ralnex $\left.{ }^{\circledR}\right)$ on TEC of cattle for 28 days was shown in Table 2 and Figure 2.

The pre-treatment mean values of TEC (million/cu.mm of blood) were $5.88 \pm 0.10,6.00 \pm 0.07$ and $5.82 \pm 0.13$ in the groups of A, B and $\mathrm{C}$ respectively. On the 28th day of post treatment the mean values of TEC significantly increased up to $7.44 \pm 0.07,6.74 \pm 0.10$ and $7.06 \pm 0.07$ in the groups of $\mathrm{A}, \mathrm{B}$ and $\mathrm{C}$ respectively. The mean value of TEC in control group D was $5.96 \pm 0.05$ but the mean values of TEC gradually decreased and on 28th day it was $5.76 \pm 0.05$.

\subsubsection{Hemoglobin content (gm \%)}

The effect of Albendazole (Helmex-vet $\left.{ }^{\circledR}\right)$, Fenbendazole (Peraclear $\left.{ }^{\circledR}\right)$ and Levamisole (Ralnex $\left.{ }^{\circledR}\right)$ on $\mathrm{Hb}$ of cattle for 28 days was shown in Table 3 and Figure 3.

The pre-treatment mean values of hemoglobin ( $\mathrm{gm} \%$ ) were $7.30 \pm 0.41,8.10 \pm 0.48$ and $8.30 \pm 0.46$ in the groups of A, B and C respectively. On the 28 th day of the post treatment the mean values of $\mathrm{Hb}$ were increases up to $8.70 \pm 0.34,9.40 \pm 0.37$ and $9.50 \pm 0.52$ in the groups of $\mathrm{A}, \mathrm{B}$ and $\mathrm{C}$ respectively. The mean value of $\mathrm{Hb}$ in control group $\mathrm{D}$ was $7.90 \pm 0.51$ but the mean values of $\mathrm{Hb}$ gradually decreased on 28th and it was 7.00 \pm 0.47 .

Table 2: Comparative efficacy of Albendazole (Helmex-Vet®), Fenbendazole (Peraclear®) and Levamisole (Ralnex®) at recommended doses on TEC (million/cu. mm.) in Cattle

\begin{tabular}{|c|c|c|c|c|c|c|}
\hline Groups & Drug with doses & $\begin{array}{l}\text { Pre-treatment } \\
\text { TEC at } 0 \text { day } \\
\text { Mean } \pm \text { SE }\end{array}$ & $\begin{array}{l}\text { Post treatment } \\
\text { TEC at } 7 \text { th day } \\
\text { Mean } \pm \text { SE }\end{array}$ & $\begin{array}{l}\text { TEC at 14th day } \\
\text { Mean } \pm \text { SE }\end{array}$ & $\begin{array}{l}\text { TEC at } 21 \text { st day } \\
\text { Mean } \pm \text { SE }\end{array}$ & $\begin{array}{l}\text { TEC at } 28 \text { th day } \\
\text { Mean } \pm \text { SE }\end{array}$ \\
\hline A & $\begin{array}{l}\text { Albendazole (Helmex- } \\
\text { vet }(\text { ) } 600 \mathrm{mg} / \mathrm{Tab}) 7.5 \\
\mathrm{mg} / \mathrm{kg} \text { b.wt orally }\end{array}$ & $5.88 \pm 0.10$ & $\begin{array}{l}6.34 * * \pm 0.09 \\
(7.26 \%)\end{array}$ & $\begin{array}{l}6.74 * * \pm 0.07 \\
(12.76 \%)\end{array}$ & $\begin{array}{l}7.08 * * \pm 0.07 \\
(16.95 \%)\end{array}$ & $\begin{array}{l}7.44 * * \pm 0.07 \\
(20.97 \%)\end{array}$ \\
\hline B & $\begin{array}{l}\text { Fenbendazole (Pera- } \\
\text { clear®) } 250 \mathrm{mg} \text { /bolus) } \\
7.5 \mathrm{mg} / \mathrm{kg} \text { b.wt orally }\end{array}$ & $6 \pm 0.07$ & $\begin{array}{l}6.32 * * \pm 0.08 \\
(5.06 \%)\end{array}$ & $\begin{array}{l}6.52 * * \pm 0.10 \\
(7.98 \%)\end{array}$ & $\begin{array}{l}6.64 * * \pm 0.10 \\
(9.64 \%)\end{array}$ & $\begin{array}{l}6.74 * * \pm 0.10 \\
(10.98 \%)\end{array}$ \\
\hline $\mathrm{C}$ & $\begin{array}{l}\text { Levamisole (Ralnex®) } \\
708 \mathrm{mg} / \text { bolus) } 7.5 \mathrm{mg} / \mathrm{kg} \\
\text { b.wt orally }\end{array}$ & $5.82 \pm 0.13$ & $\begin{array}{l}6.24 * * \pm 0.12 \\
(6.73 \%)\end{array}$ & $\begin{array}{l}6.64 * * \pm 0.11 \\
(12.35 \%)\end{array}$ & $\begin{array}{l}6.90 * * \pm 0.09 \\
(15.65 \%)\end{array}$ & $\begin{array}{l}7.06 * * \pm 0.07 \\
(17.56 \%)\end{array}$ \\
\hline D & Control & $5.96 \pm 0.05$ & $\begin{array}{l}5.94 \pm 0.05 \\
(0.34 \%)\end{array}$ & $\begin{array}{l}5.88 * \pm 0.05 \\
(1.34 \%)\end{array}$ & $\begin{array}{l}5.82 * \pm 0.04 \\
(2.35 \%)\end{array}$ & $\begin{array}{l}5.76 \pm 0.05 \\
(3.36 \%)\end{array}$ \\
\hline
\end{tabular}

Within the parenthesis value showing (\% increase and decrease)

The above values represent the mean \pm SE of 5 cattle

$* *=$ Significant at 1 percent level $(\mathrm{p}<0.01)$

$*$ Significant at 5 percent level $(\mathrm{p}<0.05)$ 


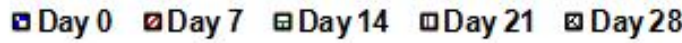

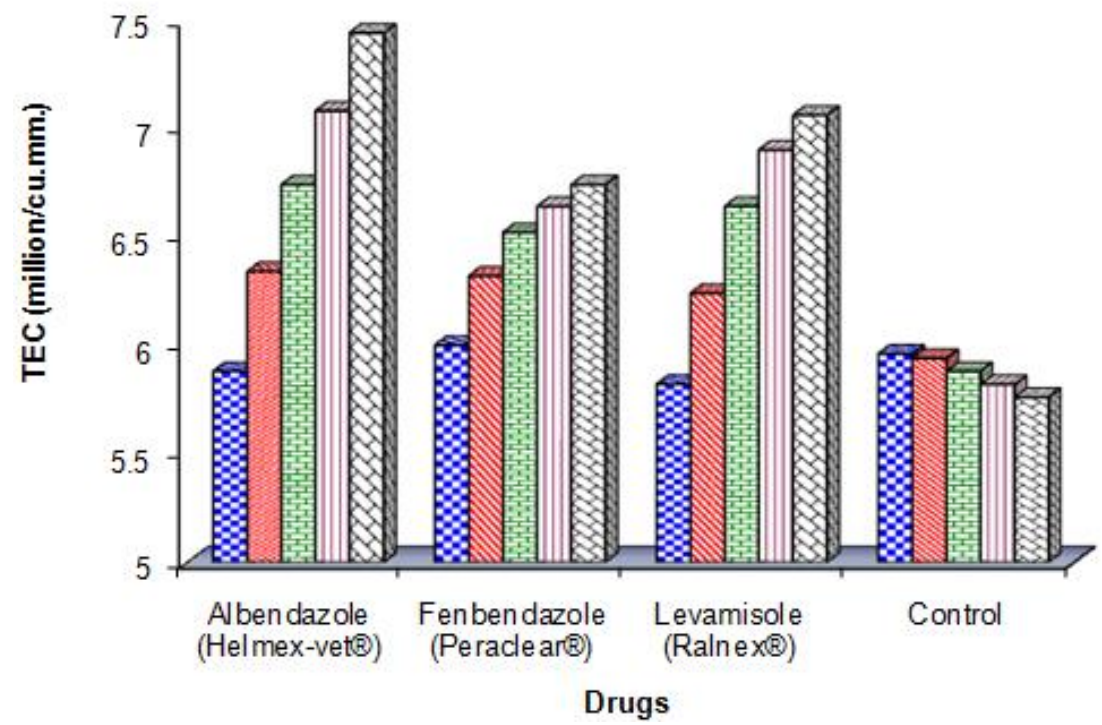

Fig. 2: Comparative efficacy of Albendazole (Helmex-Vet $\left.{ }^{\circ}\right)$, Fenbendazole (Peraclear@) and Levamisole (Ralnex®) at recommended doses on TEC (million/cu. mm.) in Cattle.

Table 3: Comparative efficacy of Albendazole (Helmex-Vet®), Fenbendazole (Peraclear®) and Levamisole (Ralnex®) at recommended doses on Hb Content (gm \%) in Cattle

\begin{tabular}{|c|c|c|c|c|c|c|}
\hline Groups & Drug with doses & $\begin{array}{l}\text { Pre-treatment } \\
\mathrm{Hb} \text { at } 0 \text { day } \\
\text { Mean } \pm \text { SE }\end{array}$ & $\begin{array}{l}\text { Post treatment } \\
\text { Hb at } 7 \text { th day } \\
\text { Mean } \pm \text { SE }\end{array}$ & $\begin{array}{l}\text { Hb at } 14 \text { th day } \\
\text { Mean } \pm \text { SE }\end{array}$ & $\begin{array}{l}\text { Hb at } 21 \text { st day } \\
\text { Mean } \pm \text { SE }\end{array}$ & $\begin{array}{l}\mathrm{Hb} \text { at } 28 \text { th day } \\
\text { Mean } \pm \text { SE }\end{array}$ \\
\hline A & $\begin{array}{l}\text { Albendazole (Helmex-vet@) } \\
600 \mathrm{mg} / \mathrm{Tab}) 7.5 \mathrm{mg} / \mathrm{kg} \text { b.wt } \\
\text { orally }\end{array}$ & $7.3 \pm 0.41$ & $\begin{array}{l}7.7 * \pm 0.41 \\
(5.19 \%)\end{array}$ & $\begin{array}{l}7.9 * * \pm 0.33 \\
(7.59 \%)\end{array}$ & $\begin{array}{l}8.4^{* *} \pm 0.33 \\
(13.10 \%)\end{array}$ & $\begin{array}{l}8.7 * * \pm 0.34 \\
(16.09 \%)\end{array}$ \\
\hline B & $\begin{array}{l}\text { Fenbendazole (Peraclear®) } \\
250 \mathrm{mg} / \mathrm{bolus}) 7.5 \mathrm{mg} / \mathrm{kg} \\
\text { b.wt orally }\end{array}$ & $8.1 \pm 0.48$ & $\begin{array}{l}8.4 \pm 0.40 \\
(3.57 \%)\end{array}$ & $\begin{array}{l}8.8 * * \pm 0.41 \\
(7.95 \%)\end{array}$ & $\begin{array}{l}9.1^{* *} \pm 0.43 \\
(10.99 \%)\end{array}$ & $\begin{array}{l}9.4 * * \pm 0.37 \\
(13.83 \%)\end{array}$ \\
\hline $\mathrm{C}$ & $\begin{array}{l}\text { Levamisole (Ralnex®) } \\
708 \mathrm{mg} / \text { bolus) } 7.5 \mathrm{mg} / \mathrm{kg} \\
\text { b.wt orally }\end{array}$ & $8.3 \pm 0.46$ & $\begin{array}{l}8.6 \pm 0.48 \\
(3.49 \%)\end{array}$ & $\begin{array}{l}9 * * \pm 0.52 \\
(7.78 \%)\end{array}$ & $\begin{array}{l}9.2 * * \pm 0.54 \\
(9.78 \%)\end{array}$ & $\begin{array}{l}9.5^{* *} \pm 0.52 \\
(12.63 \%)\end{array}$ \\
\hline $\mathrm{D}$ & Control & $7.9 \pm 0.51$ & $\begin{array}{l}7.7 \pm 0.51 \\
(2.53 \%)\end{array}$ & $\begin{array}{l}7.5 \pm 0.50 \\
(5.06 \%)\end{array}$ & $\begin{array}{l}7.2 \pm 0.44 \\
(8.86 \%)\end{array}$ & $\begin{array}{l}7.0 \pm 0.47 \\
(11.39 \%)\end{array}$ \\
\hline
\end{tabular}

Within the parenthesis value showing (\% increase and decrease)

The above values represent the mean \pm SE of 5 cattle

$* *=$ Significant at 1 percent level $(\mathrm{p}<0.01)$

$*=$ Significant at 5 percent level $(\mathrm{p}<0.05)$

Table 4: Comparative efficacy of Albendazole (Helmex-Vet ${ })$, Fenbendazole (Peraclear $\left.{ }^{\circledR}\right)$ and Levamisole (Ralnex $\left.®\right)$ at recommended doses on ESR $\left(\mathrm{mm} / 1^{\mathrm{st}}\right.$ hour$)$ in Cattle

\begin{tabular}{|c|c|c|c|c|c|c|}
\hline Groups & Drug with doses & $\begin{array}{l}\text { Pre-treatment } \\
\text { ESR at } 0 \text { day } \\
\text { Mean } \pm \text { SE }\end{array}$ & $\begin{array}{l}\text { Post treatment } \\
\text { ESR at } 7 \text { th day } \\
\text { Mean } \pm \text { SE }\end{array}$ & $\begin{array}{l}\text { ESR at } 14 \text { th day } \\
\text { Mean } \pm \text { SE }\end{array}$ & $\begin{array}{l}\text { ESR at } 21 \text { st day } \\
\text { Mean } \pm \text { SE }\end{array}$ & $\begin{array}{l}\text { ESR at } 28 \text { th day } \\
\text { Mean } \pm \text { SE }\end{array}$ \\
\hline A & $\begin{array}{l}\text { Albendazole (Helmex-vet@) } \\
600 \mathrm{mg} / \mathrm{Tab}) 7.5 \mathrm{mg} / \mathrm{kg} \mathrm{b.wt} \\
\text { orally }\end{array}$ & $1.08 \pm 0.07$ & $\begin{array}{l}1.02 \pm 0.06 \\
(5.56 \%)\end{array}$ & $\begin{array}{l}0.94 * * \pm 0.05 \\
(12.96 \%)\end{array}$ & $\begin{array}{l}0.84 * * \pm 0.05 \\
(22.22 \%)\end{array}$ & $\begin{array}{l}0.78 * * \pm 0.07 \\
(27.78 \%)\end{array}$ \\
\hline B & $\begin{array}{l}\text { Fenbendazole (Peraclear®) } \\
250 \mathrm{mg} / \mathrm{bolus}) 7.5 \mathrm{mg} / \mathrm{kg} \text { b.wt } \\
\text { orally }\end{array}$ & $1.02 \pm 0.08$ & $\begin{array}{l}0.96 \pm 0.06 \\
(5.88 \%)\end{array}$ & $\begin{array}{l}0.88 * * \pm 0.06 \\
(13.73 \%)\end{array}$ & $\begin{array}{l}0.78 * * \pm 0.06 \\
(23.53 \%)\end{array}$ & $\begin{array}{l}0.7 * * \pm 0.07 \\
(31.37 \%)\end{array}$ \\
\hline $\mathrm{C}$ & $\begin{array}{l}\text { Levamisole (Ralnex®) } \\
708 \mathrm{mg} / \mathrm{bolus}) 7.5 \mathrm{mg} / \mathrm{kg} \text { b.wt } \\
\text { orally }\end{array}$ & $0.98 \pm 0.7$ & $\begin{array}{l}0.92 \pm 0.06 \\
(6.12 \%)\end{array}$ & $\begin{array}{l}0.82 * * \pm 0.06 \\
(16.33 \%)\end{array}$ & $\begin{array}{l}0.78 \pm 0.16 \\
(20.41 \%)\end{array}$ & $\begin{array}{l}0.68 * * \pm 0.06 \\
(30.61 \%)\end{array}$ \\
\hline $\mathrm{D}$ & Control & $1.02 \pm 0.06$ & $\begin{array}{l}1.02 \pm 0.06 \\
(0.00 \%)\end{array}$ & $\begin{array}{l}1.04 \pm 0.02 \\
(1.92 \%)\end{array}$ & $\begin{array}{l}1.1^{*} \pm 0.03 \\
(7.27 \%)\end{array}$ & $\begin{array}{l}1.18 \pm 0.04 \\
(13.56 \%)\end{array}$ \\
\hline
\end{tabular}

Within the parenthesis value showing (\% increase and decrease)

The above values represent the mean \pm SE of 5 cattle

$* *=$ Significant at 1 percent level $(\mathrm{p}<0.01)$

$*=$ Significant at 5 percent level $(\mathrm{p}<0.05)$ 


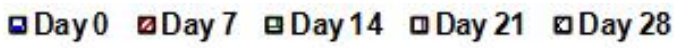

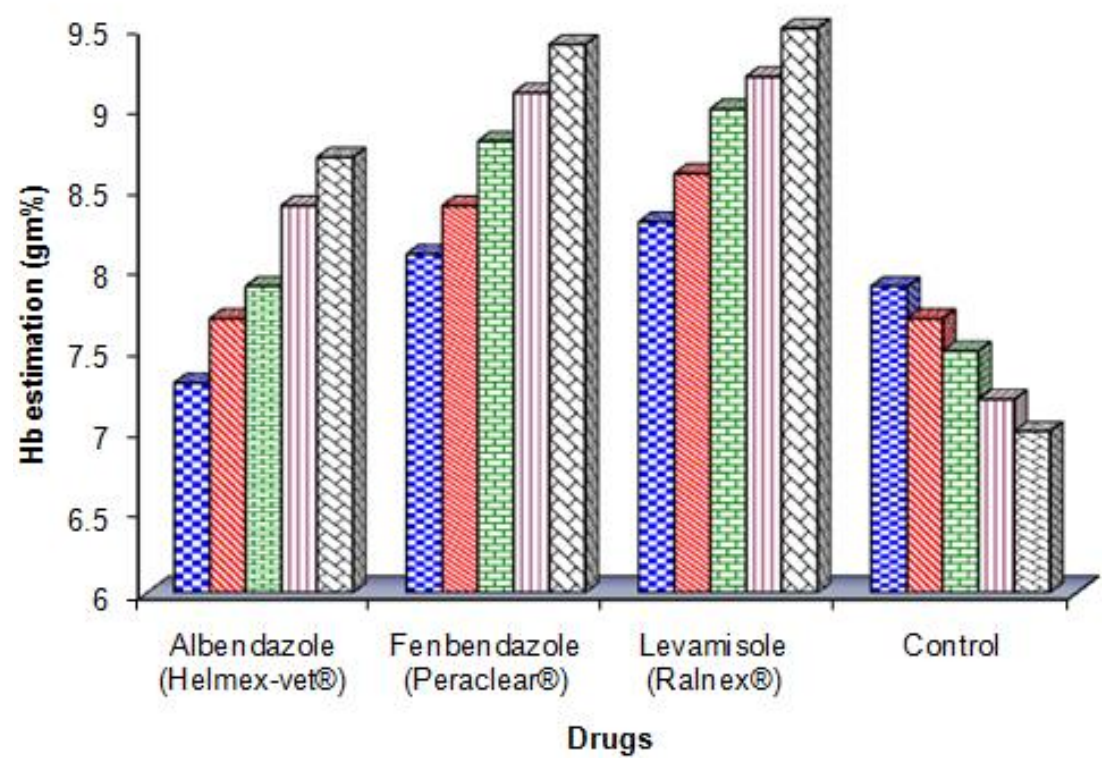

Fig. 3: Comparative efficacy of Albendazole (Helmex-Vet $($ ), Fenbendazole (Peraclear $®)$ and Levamisole (Ralnex $®)$ at recommended doses on Hb Estimation $(\mathrm{gm} \%)$ in Cattle

\subsubsection{Erythrocyte sedimentation rate (ESR, $\mathrm{mm} / \mathrm{hr})$}

The effect of Albendazole (Helmex-vet $\left.{ }^{\circledR}\right)$, Fenbendazole (Peraclear $\left.{ }^{\circledR}\right)$ and Levamisole (Ralnex ${ }^{\circledR}$ ) on ESR of cattle for 28 days was shown in Table 4 and Figure 4.

The pre-treatment mean values of ESR $(\mathrm{mm} / \mathrm{hr})$ were $1.08 \pm 0.07$, $1.02 \pm 0.08$ and $0.98 \pm 0.07$ in the groups of $\mathrm{A}, \mathrm{B}$ and $\mathrm{C}$ respectively. On the 28th day of the post treatment the mean values of ESR were $0.78 \pm 0.07,0.7 \pm 0.07$ and $0.68 \pm 0.06$ in the groups of A, B and $\mathrm{C}$ respectively. Whereas the mean ESR value of control group $\mathrm{D}$ was increased to $1.18 \pm 0.04$ on 28 th day against $1.02 \pm 0.06$ on " 0 " day.

\subsubsection{Total leukocyte counts (TLC, thousand/cu.mm of blood)}

The effect of Albendazole (Helmex-vet $\left.{ }^{\circledR}\right)$, Fenbendazole (Peraclear $\left.{ }^{\circledR}\right)$ and Levamisole (Ralnex $\left.{ }^{\circledR}\right)$ on TLC of cattle for 28 days was shown in Table 5 and Figure 5.
The pre-treatment mean values of TLC were $7.86 \pm 0.12,7.86 \pm 0.07$ and $7.8 \pm 0.10$ in the groups of $\mathrm{A}, \mathrm{B}$ and $\mathrm{C}$ respectively on 0 day and in post-treatment, the mean values of TLC were $8.16 \pm 0.09$, $8.04 \pm 0.14$ and $8.1 \pm 0.04$ in the groups of $\mathrm{A}, \mathrm{B}$ and $\mathrm{C}$ respectively on 28th day. The mean TLC values of control group was $7.92 \pm 0.12$ on " 0 " day and $7.76 \pm 0.07$ on 28 th day.

\subsubsection{Packed cell volume (PCV \%)}

The effect of Albendazole (Helmex-vet $\left.{ }^{\circledR}\right)$, Fenbendazole (Peraclear $\left.{ }^{\circledR}\right)$ and Levamisole (Ralnex $\left.{ }^{\circledR}\right)$ on PCV of cattle for 28 days was shown in Table 6 and Figure 6.

The pre-treatment mean values of PCV were $32.4 \pm 0.58$, $32.8 \pm 0.41$ and $32.1 \pm 0.53$ in the groups of $\mathrm{A}, \mathrm{B}$ and $\mathrm{C}$ respectively. On the 28th day of post-treatment, the mean values of PCV values were $33.9 \pm 0.43,34.7 \pm 0.37$ and $33.7 \pm 0.44$ in the groups of $\mathrm{A}, \mathrm{B}$ and $\mathrm{C}$ respectively. Whereas the mean PCV values of control group D was $32.4 \pm 0.44$ on " 0 " day and $31.2 \pm 0.34$ on 28 th day.

口Day 0 घDay 7 घDay 14 ФDay 21 口Day 28

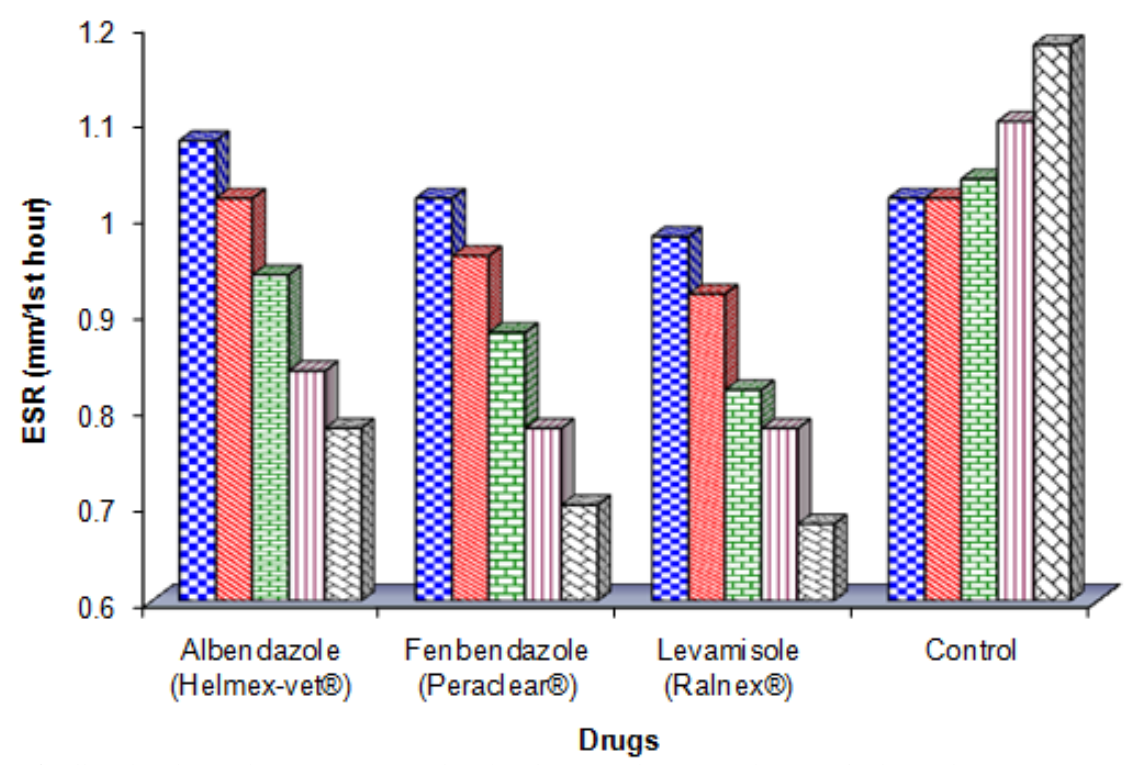

Fig. 4: Comparative efficacy of Albendazole (Helmex-Vet®), Fenbendazole (Peraclear®) and Levamisole (Ralnex®) at recommended doses on ESR $(\mathrm{mm} / 1 \mathrm{st}$ hour) in Cattle 
Table 5: Comparative efficacy of Albendazole (Helmex-Vet®), Fenbendazole (Peraclear®) and Levamisole (Ralnex®) at recommended doses on TLC (Thousand/cu. mm.) in Cattle

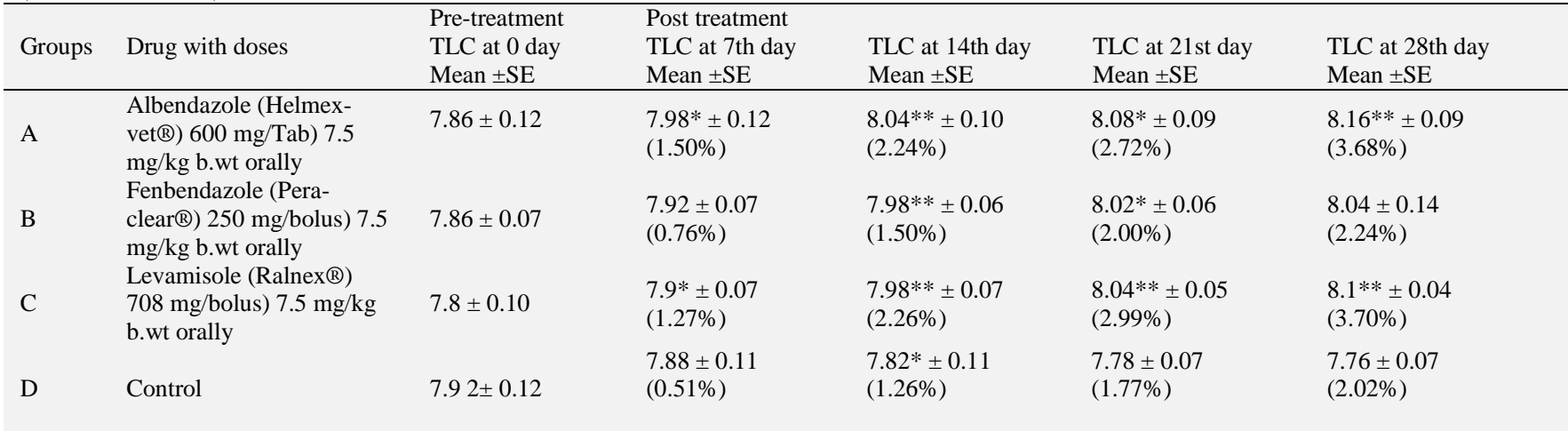

Within the parenthesis value showing (\% increase and decrease)

The above values represent the mean \pm SE of 5 cattle

$* *=$ Significant at 1 percent level $(\mathrm{p}<0.01)$

$*$ Significant at 5 percent level $(\mathrm{p}<0.05)$

Table 6: Comparative efficacy of Albendazole (Helmex-Vet巴), Fenbendazole (Peraclear®) and Levamisole (Ralnex $\left.{ }^{\circledR}\right)$ at recommended doses on PCV (\%) in Cattle

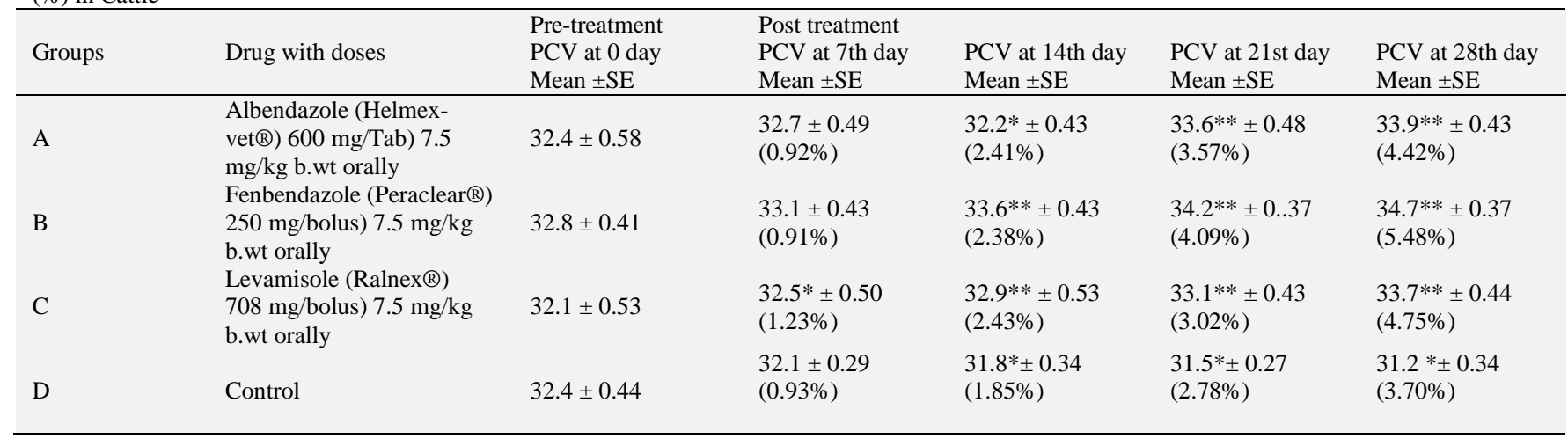

Within the parenthesis value showing (\% increase and decrease)

The above values represent the mean \pm SE of 5 cattle

$* *$ Significant at 1 percent level $(\mathrm{p}<0.01)$

$*=$ Significant at 5 percent level $(\mathrm{p}<0.05)$

๑Day 0 Day 7 aDay 14 口Day 21 aDay 28

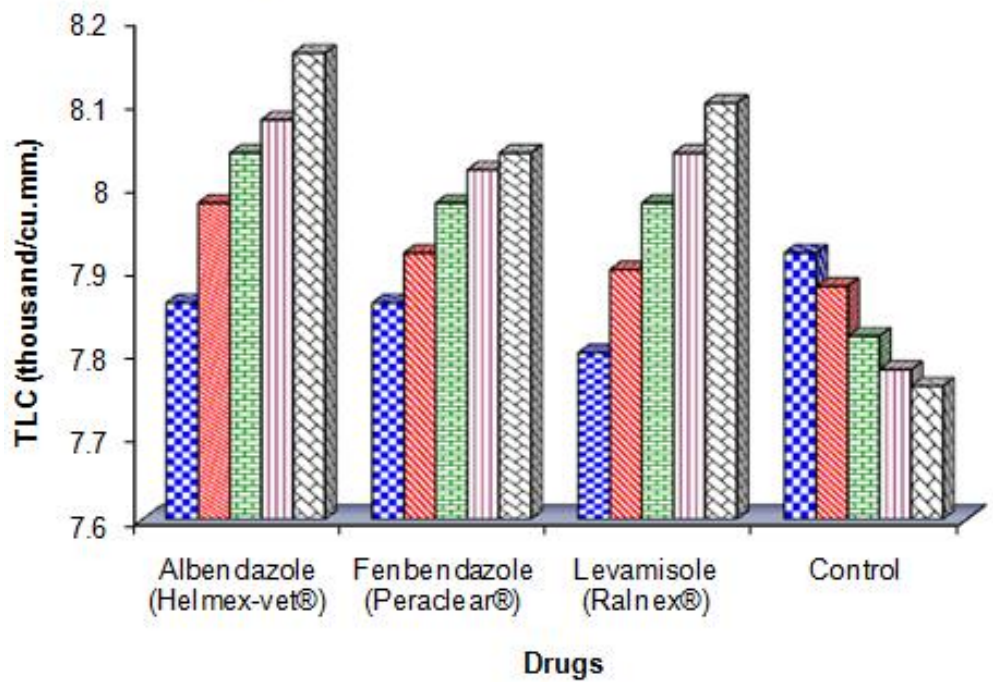

Fig. 5: Comparative efficacy of Albendazole (Helmex-Vet $\left.{ }^{\circledR}\right)$, Fenbendazole (Peraclear®) and Levamisole (Ralnex $\left.{ }^{\circledR}\right)$ at recommended doses on TLC (Thousand/cu. mm.) in Cattle. 


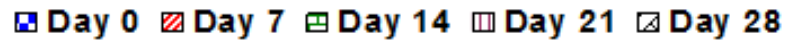

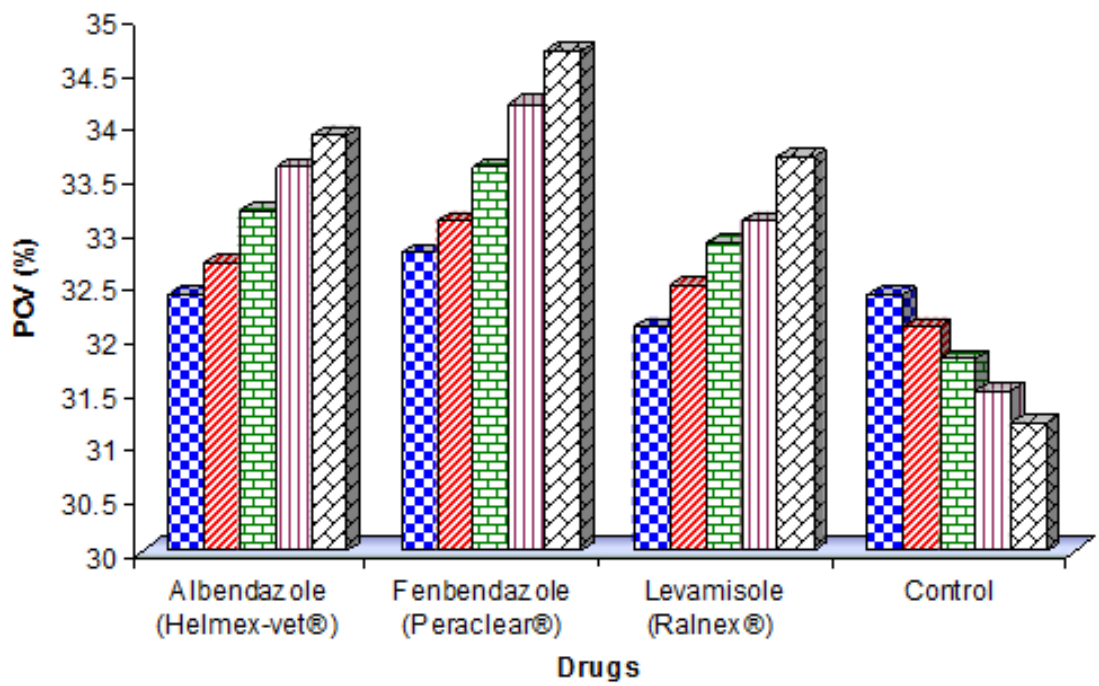

Fig. 6: Comparative efficacy of Albendazole (Helmex-Vet $\left.{ }^{\circledR}\right)$, Fenbendazole (Peraclear $\left.{ }^{\circledR}\right)$ and Levamisole (Ralnex®) at recommended doses on Packed Cell Volume PCV $(\%)$ in Cattle.

\section{Discussion}

Gastrointestinal parasites are widely distributed among the cattle population in Bangladesh. The climatic condition of this country is very favorable for survival and propagation of parasites and their intermediate host. The study was undertaken to study the comparative efficacy of Albendazole (Helmex-vet $\left.{ }^{\circledR}\right)$, Fenbendazole (Peraclear $\left.{ }^{\circledR}\right)$ and Levamisole (Ralnex $\left.{ }^{\circledR}\right)$ against gastrointestinal nematodiasis in cattle and to study the effects of these anthelmintics on haematological parameters in cattle. Although, there was a big difference among the findings of different researchers. However, slight difference observed in the present study may be due to difference of nutritional status of the cattle, pasture management and geo-ecological conditions.

4.1. Studies on comparative efficacy of Albendazole (Helmex-vet®), Fenbendazole (peraclear ${ }^{\circledR)}$ and Levamisole (ralnex $\left.{ }^{\circledR}\right)$ against gastrointestinal nematodiasis in cattle

The efficacy of different anthelmintics was recorded on the basis of faecal egg count of the treated cattle.

The efficacy of Albendazole (Helmex-vet $\AA$ ) was $93.58 \%$ in the present study. This result is more or less similar reported by earlier workers, (Theodorides et al. 1976, Williams et al. 1977, Wescott et al. 1979, Partani et al. 1995, Anwar et al. 1996, Willams et al. 1997, Amin et al. 2005, Soutello et al. 2007). But some earlier workers reported $100 \%$ efficacy of Albendazole against gastrointestinal nematodiasis, (Borgsteed 1979, Dzakula et al. 1985, Yadav and Kumar 1990, Sharma 1992, Nwosu et al. 2007, Demeler et al. 2009).

The efficacy of Fenbendazole (Peraclear®) was $90.56 \%$. This result is more or less similar by earlier reported (Craig and Bell 1978, Jagannath et al. 1988, Maqbool et al. 1996, Atanásio et al. 2002, Amin et al. 2005). However, some workers reported variable efficacy, Sinha et al. (1987), 99.68\%-99.91\% efficacy, Maqbool et al. (1996) 72\%-92.40\% efficacy, Jagannath et al. (1988) 80-100\% efficacy.

The efficacy of Levamisole (Ralnex ${ }^{\circledR}$ ) was $93.93 \%$ against gastrointestinal nematodiasis. More or less similar result was found by earlier workers, (Beck et al. 1991, Craig et al. 1978, Sharma and Jagadish 1991, Prodhan et al. 1993, Thejomoorthy et al. 1995, Vesconcelos et al. 1995 and Williams and Broussared 1995, Nwosu et al. 2007, Soutello et al. 2007).

\subsection{Studies on the efficacy of Albendazole (Helmex- vet $(\AA)$, Fenbendazole (Peraclear $\left.{ }^{\circledR}\right)$ and Levamisole (Ralnex®) on haematological parameters}

The changes of haematological parameters in cattle affected with the gastrointestinal nematodes were determined at pre and post treatment with Albendazole (Helmex-vet $\left.{ }^{\circledR}\right)$, Fenbendazole (Peraclear $\left.{ }^{\circledR}\right)$ and Levamisole (Ralnex $\left.{ }^{\circledR}\right)$. The mean value of total erythrocyte count (TEC) was decreased in gastrointestinal nematodes affected cattle. These results are in agreement with the report, Sahia (1966), Ogunsusi (1978), Serikbaeva (1981), Akbaev (1986), Ahmed and Ansari (1989) and Prodhan et al. (1991), Willams and Broussand (1995), Soutello et al. (2007), Demeler et al. (2009). The mean value of total erythrocyte count (TEC) was increased significantly $(\mathrm{p}<0.01)$ from 14 th day to 28 th day of the treatment with anthelmintics. These results are more or less similar with the earlier workers, (Nettleton and Beckett 1976, Anwar et al. 1996, Soutello et al. 2007, Demeler et al. 2009).

In present study the haemoglobin value $(\mathrm{Hb})$ decreased in affected cattle. This result is in agreement with the workers of Sahia (1966), Silverman et al. (1970), Ogunsusi (1978), Akbaev (1986), Ahmed and Ansari (1989), Prodhan et al. (1991) Amin et al. (2005).

The haemoglobin value increased significantly $(\mathrm{p}<0.01)$ from 14 th day to 28th day of anthelmintic treatment. These findings were more or less similar by the workers, Wilson (1969), Nettleton and Beckett (1976), Mukherjee (1992), Anwar et al. (1996), Soutello et al. (2007), Nwosu et al. (2007).

The erythrocyte sedimentation rate (ESR) reduced significantly $(\mathrm{p}<0.01)$ from the 14th to 28th days of treatment. This result is similar to the report of Sahia (1966), Fitzeimmons et al. (1968), Nettleton and Beckett (1976) and Prodhan et al. (1991), Mortensen et al. (2003), Demeler et al. (2009).

The total leukocyte count (TLC) reduced significantly $(\mathrm{p}<0.01)$ from the 14th to 28th days of treatment. This result is similar to the report of Ogunsusi (1978), Akbaev (1986), Ahmed and Ansari (1989), Anwar et al. (1996), Amin et al. (2005), Soutello et al. (2007).

The packed cell volume (PCV) value increased significantly $(p<0.01)$ from 14th day and continued up to 28th day of treatment and declined PCV value was observed in control group. This finding supports the earlier workers of Sahia (1966) Nettleton and Beckett (1976), Prodhan et al. (1991), Anwar et al. (1996), Amin et al. (2005), Soutello et al. (2007). 


\section{Conclusion}

The finding of the present study reveals that Helmex-vet@, Peraclear ${ }^{\circledR}$ and Ralnex ${ }^{\circledR}$ are highly effective for reduction of EPG of gastrointestinal nematodes in Bangladesh. These three drugs have wide therapeutic index and they may kill or inhibit egg production of gastrointestinal nematodes. However, the present result is preliminary control efficacy studies of anthelmintics which may help the future researchers to explore the details pharmacokinetic and toxic effects for wide therapeutic uses in Bangladesh for the treatment of parasitic infection in cattle.

\section{Acknowledgements}

Authors are grateful and indebted to the almighty God without whose grace they would have ever been able to pursue their higher studies in this field of science. They also express their deep sense of gratitude and immense indebtedness to the Sylhet Agricultural University, Sylhet and the authority of the library of Bangladesh Agricultural University, Mymensingh, Bangladesh for collection of article and successful completion of their research work and preparation of this manuscript.

\section{References}

[1] Ahmed M \& Ansari JA (1989) Effect of Haemonchosis on hematology and non-specific Phosphomonoesterase activities in sheep and goats. Helminthology 26(4), 295-302.

[2] Ahmed R (1972) parasitic picture and livestock productivity in Eas Pakistan. In: Activities of the Research section of Directorate of livestock Services, Bangladesh 2, and 32-35.

[3] Akbaev MS (1986) Blood picture of sheep infected with Moniezia expansa. Moskovskaya Veteinarnaya Akademiya 3, 287-290.

[4] Amin MR, Khalid SMA, Alam MO, Mostofa M, Paul BK \& Shahiduzzaman M (2005) Effects of Helmex and Peraclear? Against Gastro-Intestinal Nematodiasis in Sheep. Journal of Animal and Veterinary Advances 4(1), 58-62.

[5] Anwar AH, Hayet CS \& Amir MI (1996) Prevalence of gastrointestinal helminthiasis and comparative efficacy of anthelmintics in parasitizded buffalo calves. Pakistan Veterinary Journal 16(4), 160163.

[6] Asian development Bank-ADB (1984) Annual report on agricultura development. Livestock Sector 24(7).

[7] Atanásio A, Boomker J \& Sitoe C (2002) A survey on the occurrence of resistance to anthelmintics of gastrointestinal nematodes of goats in Mozambique. Onderstepoort Journal of Veterinary Research 69(3), 215-20.

[8] Beck AAH, Beck AA \& Moreira WS (1991) Levamisole in sheep Revistadocenteo da ciecias Russis 1,113-120.

[9] Bhuiyan AKFH (2007) Cattle and livelihood in Bangladesh. Article from web resource. http://www.vishwagou. org/ date 02/09/2008.

[10]Borgsteed FHM (1979) the activity of Albendazole against adult and larval gastro-intestinal nematodes in naturally infected calves in the Netherlands. Veterinary Quarterly report 1(4), 181-188.

[11]Craig TM \& Bell RR (1978) Evolution of Levamisole and Fenbendazole as an anthelmintic for gastro-intestinal nematodes of cattle American Journal of Veterinary Research 39(6), 1037-1038.

[12]Debnath NC, Taimur AK, Saha M, Ersaduzaman M, Heleluddin ML Rahman DK, Roy MJFA \& Islam MA (1995) A retrospective study of calf losses on the central dairy cattle breeding station in Bangladesh. Prev Vet Med. 24, 43-53. http://dx.doi.org/10.1016/01675877(95)00471-8.

[13]Demeler J, Van Zeveren AM, Kleinschmidt N, Vercruysse J, Höglund J, Koopmann R, Cabaret J, Claerebout E, Areskog M \& von SamsonHimmelstjerna G (2009) Monitoring the efficacy of ivermectin and albendazole against gastro intestinal nematodes of cattle in Northern Europe. Veterinary Parasitology 160(1-2), 109-15. http://dx.doi.org/10.1016/i.vetpar.2008.10.030.

[14]DLS (2007-2008) Livestock conservation and development program, Directorate of Livestock Services, Farmgate, Dhaka, Bangladesh.

[15]Dzakula AN, Rapic D \& Zukovic M (1985) Efficacy of albendazole, (Monil) against gastro-intestinal nematodes and liver flukes in cattle and sheep. Praxiz Veterinaia 33(1-2), 167-171.
[16]Economic index (2010) Finance division, Ministry of Finance, Government of the People Republic of Bangladesh, www.mof.gov.bc

[17]Fitzimmons WM, Harness EI \& Sellwoojd SA (1968) Experimental TrichoTrichuris spp. infection in adult goats. Res. Vet. Sci 9(3), $237-$ 247.

[18]Gupta SP (1978) Statistical method $1^{\text {st }}$ Ed. Sulton Chand and Sons Pub. Daryangang. New-Delhi 110002, India.

[19]Hosking BC, Stein PA, Mosimann D, Seewald W, Strehlau G \& Kaminsky R (2008) Dose determination studies for monepantel, an amino-acetonitrile derivative, against fourth stage gastro-intestinal nematode larvae infecting sheep Veterinary Parasitology 157(1-2), 72-80. http://dx.doi.org/10.1016/j.vetpar.2008.07.014.

[20]Jagannath MSD, Sonza PE \& Rahman AS (1988) Clinical trials with fenbendazole against strongyle infection in dairy cattle. Livestock Adv 13, 39-41.

[21] Maqbool A, Rahman F \& Afzal M (1996) Comparative anthelmintic efficacy of fenbendazole, tetramisole and morantel tartrate against ascariasis in buffalo calves. Buffalo Journal 12, 343-346.

[22] Mason JL \& Buramendram V (1982) Breeding plans for ruminant livestock in the tropics. FAO, Animal Production and Health paper 136, 34-89.

[23] Mortensen LL, Williamson LH, Terrill TH, Kircher RA, Larsen M \& Kaplan RM (2003) Evaluation of prevalence and clinical implications of anthelmintic resistance in gastrointestinal nematodes in goats. Journal of American Vetetrinary Medical Association 223(4), 495-500. http://dx.doi.org/10.2460/javma.2003.223.495.

[24] Motalib MA \& Alam MS (1983) the possible economic effect of gastro-intestinal nematodes in young cattle in Pabna Milk-shed, Area of Bangladesh. Bangladesh Veterinary Journal 17(1-4), 5-9.

[25] Mukherjee BN (1992) Efficacy of Albendazole against gastrointestinal nematodes in naturally infected calves. Indian Veterinary Medical Journal 16(4), 292-295.

[26] Nettleton D \& Beckett P (1976) Hematology of the indigenous goat in Switzerland. Tropical Animal Health and Production 8, 60-61. http://dx.doi.org/10.1007/BF02383368.

[27] Nwosu CO, Eneme TA, Onyeyili PA \& Ogugbuaja VO (2007) Toxicity and anthelmintic efficacy of crude aqueous of extract of the bark of Sacoglottis gabonensis. Fitoterapia 79(2), 101-5. http://dx.doi.org/10.1016/j.fitote.2007.07.010.

[28] Ogunsusi RA (1978) Changes in Blood value of sheep suffering from acute and chronic helminthes. Research in Veterinary Science 25(3), 298-301.

[29]Partani AK, Kumar D, Manoha, GS \& Kumar R (1995) Comparative efficacy of some anthelmintics against gastro-intestinal nematodes in camel. Journal of Camel Practice and Research 2, 97-99.

[30]Prodhan KB, Thakur DK \& Sudham NA (1991). Haematobiochemical changes in calves with natural helminthic infection in Ranchi. J. Res. Agric. University. 3 (1), 119-121.

[31]Prodhan KB, Thakur DK \& Sudham NA (1993) Comparative efficacy of ivermectin and Levamisole hydrochloride against nematodiasis in calves. Journal of Research, Birsa Agricultural University 5(2), 187 189.

[32]Qadir ANMA (1981) a preliminary study on the epidemiology of Fascioliasis in goats. Bangladesh Veterinary Journal 15, 13-17.

[33]Rahman MH \& Razzak A (1973) Incidence of helminth parasites infecting cattle Kotwali Thana of Comilla. First Bangladesh Veterinary Conference in Agricultural University Campus, Mymensingh, pp. 25

[34] Sahia BN (1966) Studies in blood picture in stomach worm infection in sheep and goats. Indian Veterinary Journal 43(5), 422-426.

[35] Samanta A \& Santra PK (2009). Prevalence of gastrointestinal helminthes in hot and humid zone of West Bengal. Journal of Veterinary Parasitology 23 (1), 50-55.

[36] Serikbaeva BK (1981) Pathological and immunological change during Trichostrongylus and Haemonchus infection in sheep. Vostochnoe otdelenic Voskhnil, pp. 122-130.

[37]Shahiduzzaman AKM, Talukder MH \& Rahman MH (1999) Ecology of periphrastic stages of Strongyles of ruminants in Bangladesh. Bangladesh Veterinary Journal 33(3-4), 93-97.

[38] Sharma LK (1992) Efficacy of anthelmintics administered through capsule against natural gastro-intestinal nematodes in cattle. Indian Veterinary Journal 69, 1134-1135.

[39] Sharma LK \& Jagadish S (1991) Efficacy of Levamisole administered through different routes against gastro-intestinal nematodes in crossbreed cattle. Indian Veterinary Journal 68, 16-18.

[40]Silverman PH, Mansfield ME \& Scott HL (1970) Contortus, infection in sheep, effects of various leaves of primary infection on nopan treated lambs. American Journal of Veterinary Research 31(5), 841-857. 
[41] Sinha HK, Grisvastava PS, Singh SP, Singh VK \& Singh SRP (1987) Efficacy of various anthelmintics on the mortality of the infective larvae of Toxocara vitulorum and treatment of calf ascariasis. Indian journal of animal sciences 57, 185-188.

[42] Soulsby EJL (1982) Helminth, Arthropods and protozoa of domestic animals $7^{\text {th }}$ Ed. E.L.S. 13 Pub. Tindall, Castell London. pp. 763-766.

[43]Soulsby EJL (1986) Helminths, Arthropods and Protozoa of Domesticated Animals, 7th Ed, The ELBS and Baillier Tindall, London, UK.

[44] Soutello RG, Seno MC \& Amarante AF (2007) Anthelmintic resistance in cattle nematodes in northwestern São Paulo State, Brazil. Veterinary Parasitology 148(3-4), 360-364.

[45] Thejomoorthy P, Sundararama MN, Napolean RE \& Gajendran K (1995) Comparative efficacy of fenbendazole and Levamisole against nematodes in calves. Cheiron 24(5-6), 154-162.

[46] Theodorides VJ, Nawalinski T, Murphy J \& Freeman J (1976) Efficacy of albendazole against against-intestinal nematodes of cattle. American journal of veterinary research 37(12), 1517-1518.

[47]Vesconcalos OT, Costa AJ, Aranties GJ, Barbosa OF \& Paulillo AC (1995) Anthelmintics activity of pour on levamisole against gastrointestinal nematodes in cattle. Revista Brasileira de Parasitologia Veterinaria 4, 95-98.

[48] Wescott RB, Farrell CJ, Gallina AM \& Foreyt WJ (1979) Efficacy of albendazole for treatment of naturally acquired nematodes infections in cattle in Washington. American journal of veterinary research 40(3), 369-371.

[49] Willams JC \& Broussand SD (1995) Comparative efficacy of Levamisole thiabendazole and fenbendazole against cattle gastro-intestinal nematodes. Veterinary $\quad$ Parasitology 58, 83-90. http://dx.doi.org/10.1016/0304-4017(94)00701-D.

[50]Willams JC, Sheehan D \& Fuselier RH (1977) Effect of albendazole on gastro-intestinal parasites of cattle. American journal of veterinary research 38(12), 2037-2038.

[51]Wilson LL (1969) Effects of Haemonchus Contortus inoculation on growth rate, feed efficacy and hematology of feeder lambs. Veterinary medicine 64(1), 59-62.

[52]Yadav L \& Kumar S (1990). Trial of albendazole and nematodes against natural gastro-intestinal nematodes of Camels. Indian Veterinary Journal 67,864 